\title{
Late summer distribution and abundance of ice-associated whales in the Norwegian High Arctic
}

\author{
Jade Vacquié-Garcia ${ }^{1, *}$, Christian Lydersen ${ }^{1}$, Tiago A. Marques ${ }^{2,3}$, Jon Aars ${ }^{1}$, \\ Heidi Ahonen ${ }^{1}$, Mette Skern-Mauritzen ${ }^{4}$, Nils Øien ${ }^{4}$, Kit M. Kovacs ${ }^{1}$ \\ ${ }^{1}$ Norwegian Polar Institute, Fram Centre, 9296 Tromsø, Norway \\ ${ }^{2}$ Centre for Research into Ecological \& Environmental Modelling (Scottish Oceans Institute), Buchanan Gardens, St Andrews, \\ KY16 9LY, UK \\ ${ }^{3}$ Centro de Estatística e Aplicações da Universidade de Lisboa, Campo Grande, 1749-016 Lisboa, Portugal \\ ${ }^{4}$ Institute of Marine Research, 5817 Bergen, Norway
}

\begin{abstract}
The Arctic is experiencing rapid warming, and resultant sea ice losses represent a serious threat to ice-associated species in the region. This study explored the distribution and abundance of the 3 Arctic resident whale species: narwhals, bowhead and white whales, in the marginal ice zone and into the sea ice north of the Svalbard Archipelago. Line-transect surveys were conducted using a combination of helicopter-based and ship-based efforts in August 2015. Twenty-six sightings, involving 27 bowhead whales and 58 narwhals, occurred along the helicopter transects, while no whales were recorded along ship transects. No white whales were observed during these surveys. After correcting for surface availability, distance sampling produced abundance estimates of $343(\mathrm{CV}=0.488)$ bowhead whales and $837(\mathrm{CV}=0.501)$ narwhals within the $52919 \mathrm{~km}^{2}$ study area. Bowhead whales were predominantly seen close to the ice-edge, whereas narwhals were located deeper into the ice. To contextualize these results within the broader Svalbard cetacean community, all whale sightings from the Norwegian Polar Institute's Svalbard Marine Mammal Sighting Data Base, from the period of the survey, were mapped to compare general distributions. These opportunistic sightings included numerous cetacean species, especially seasonally occurring ones. However, white whales dominated in terms of the numbers of individuals reported. Our results suggest little spatial overlap between seasonally occurring whales and the 3 Arctic resident whales. Bowhead whales and narwhals were tightly associated with sea ice, and white whales were tightly coastal. In contrast, the seasonally occurring species were found over the shelf and along its edges.
\end{abstract}

KEY WORDS: Abundance Arctic $\cdot$ Belugas $\cdot$ Bowhead whales $\cdot$ Climate change $\cdot$ Distribution $\cdot$ Narwhals $\cdot$ Svalbard $\cdot$ White whales

\section{INTRODUCTION}

Climate change has already caused warming of the atmosphere and oceans (IPCC 2013). In the oceans, this warming results in deepening of the thermocline, increased ocean stratification, decreased dissolved oxygen at depth as well as reduction of sea ice cover (Joos et al. 2003, Bailleul et al. 2015). The Arctic region is changing most rapidly, with sea ice los-

${ }^{*}$ Corresponding author: jadevacquiegarcia@gmail.com

$\S_{\text {Corrections were made after publication. For details see }}$ www.int-res.com/abstracts/esr/v32/c_p59-70/

This corrected version: April 4, 2017 ses being one of the most visible climate-induced changes to date (Walsh 2008, Onarheim et al. 2014). The Svalbard Archipelago in Norway is an Arctic 'hot spot', which is experiencing anomalously high losses of sea ice in terms of overall extent, thickness, proportion of multiyear ice and seasonal duration of sea ice, as well as large increases in both air and water temperatures (Pavlov et al. 2013, Nordli et al. 2014, Laidre et al. 2015, Stephenson \& Smith 2015).

() The authors 2017. Open Access under Creative Commons by Attribution Licence. Use, distribution and reproduction are unrestricted. Authors and original publication must be credited. 
Physical models predict that a seasonally ice-free Arctic could be a reality before the end of the century (Overland \& Wang 2010). A further reduction in sea ice cover, or its total absence in summer, is expected to have serious biological consequences. Among other things, such conditions will affect the distribution, the behaviour and the abundance of the species that have become residents of this unique habitat, including the Arctic ice-associated cetaceans (Kovacs et al. 2011b). For these 3 whale species - bowhead whales Balaena mysticetus, narwhal Monodon monoceros and white whale (or belugas) Delphinapterus leucas - the Arctic sea ice has been a spatially extensive, virtually disease-free, low-competition environment that provides shelter from storms and predators as well as a spatially predictable, seasonally rich food supply, particularly in the marginal ice zone (MIZ), i.e. the transition between the open ocean and sea ice (Heide-Jørgensen \& Laidre 2004). Although the Arctic resident ice-associated cetaceans are adapted to a fluctuating environment and have an ability to endure drastic changes in environmental conditions (Harington 2008), increased warming with reduced sea ice cover is expected to cause changes to the food web that will have negative effects on the quality and quantity of their traditional lipid-rich Arctic prey species (Barber \& Iacozza 2004). Changes in sea ice extent will also provide access to formerly ice-covered environments for seasonally occurring 'open-water' cetacean species such as blue whales Balaenoptera musculus, which come to the Arctic during summer (Kovacs \& Lydersen 2008, Laidre et al. 2008, 2015). A northward expansion of seasonally occurring cetaceans that will likely spend longer seasons in the Arctic will be likely to increase predation pressure and competitive stress on the resident cetacean populations (Reeves et al. 2014).

All 3 Arctic ice-associated cetacean species reside in the Svalbard area. The IUCN Red List of Threatened Species classifies both narwhals and white whales as 'Near Threatened' (Jefferson et al. 2012a,b), and the Svalbard stock of bowhead whales is classified as 'Critically Endangered' (Reilly et al. 2012). A few studies have documented regional distribution and movements of these whales for parts of the year (Lydersen et al. 2001, 2002, 2007, 2012, Wiig et al. $2007,2010)$. However, these species have never been surveyed in the Svalbard area, and population numbers are unknown. Due to the lack of baseline data, our current capacity to predict and test impacts of various stressors associated with climate change on these cetaceans is very limited.
The main objective of this study was to improve our understanding of the current distribution of the 3 Arctic resident ice-associated cetacean species and to provide abundance estimates for these populations in the Norwegian Arctic. This was attempted via combined helicopter- and ship-based line-transect surveys conducted in the MIZ and sea ice north of the Svalbard Archipelago. Secondly, the results of these MIZ surveys were put into the context of the broader cetacean community frequenting the Svalbard area in summer using the Norwegian Polar Institute's Marine Mammal Sighting Database (MMSD, www. npolar.no/en/services/mms/index.html) to investigate potential spatial overlap between resident and seasonally occurring species.

\section{MATERIALS AND METHODS}

\section{Helicopter- and ship-based surveys}

Two different cetacean surveys, involving helicopter- and ship-based line transects, were conducted from the Russian border in the east $\left(35^{\circ} \mathrm{E}\right)$ to northwest of Svalbard in the west $\left(7^{\circ} \mathrm{E}\right)$ during the summer of 2015 (in collaboration with a polar bear Ursus maritimus survey). These 2 surveys were conducted in parallel between 04 August and 30 August 2015 and in a complementing pattern. The aerial survey lines were flown using a Eurocopter AS350 Ecureuil helicopter equipped with flat windows. The 'RV Lance' (between 04 August and 22 August) and then the 'KV Svalbard' (between 22 August and 30 August) provided mobile bases for the helicopter. Transect lines were flown whenever weather conditions permitted (visibility greater than 2 nautical miles [nmi]). Flying was done at $\sim 60 \mathrm{~m}$ (200 ft) above ice/water, at a speed of $\sim 185 \mathrm{~km} \mathrm{~h}^{-1}$ (100 knots), with lines going from the ice edge (characterized by the limit of $10 \%$ of sea ice) northward (straight lines, perpendicular to the ice edge) to a distance of approximately $185 \mathrm{~km}$ into the ice (Fig. 1). Spacing between each transect line was originally set to $9 \mathrm{~km}$; however, in practice, some half-spacing lines were also flown when weather conditions prevented movement out of a particular area. Concurrent with the aerial survey, a line-transect survey was conducted by the ship(s) that supported the helicopter. The ship transects followed a zigzag design; lines were $5 \mathrm{nmi}$ long with $2.5 \mathrm{nmi}$ spacing between respective endpoints of the transects (Fig. 1). The ship(s) travelled at $\sim 18.5 \mathrm{~km} \mathrm{~h}^{-1}$ (10 knots), moving within the MIZ, from the ice 


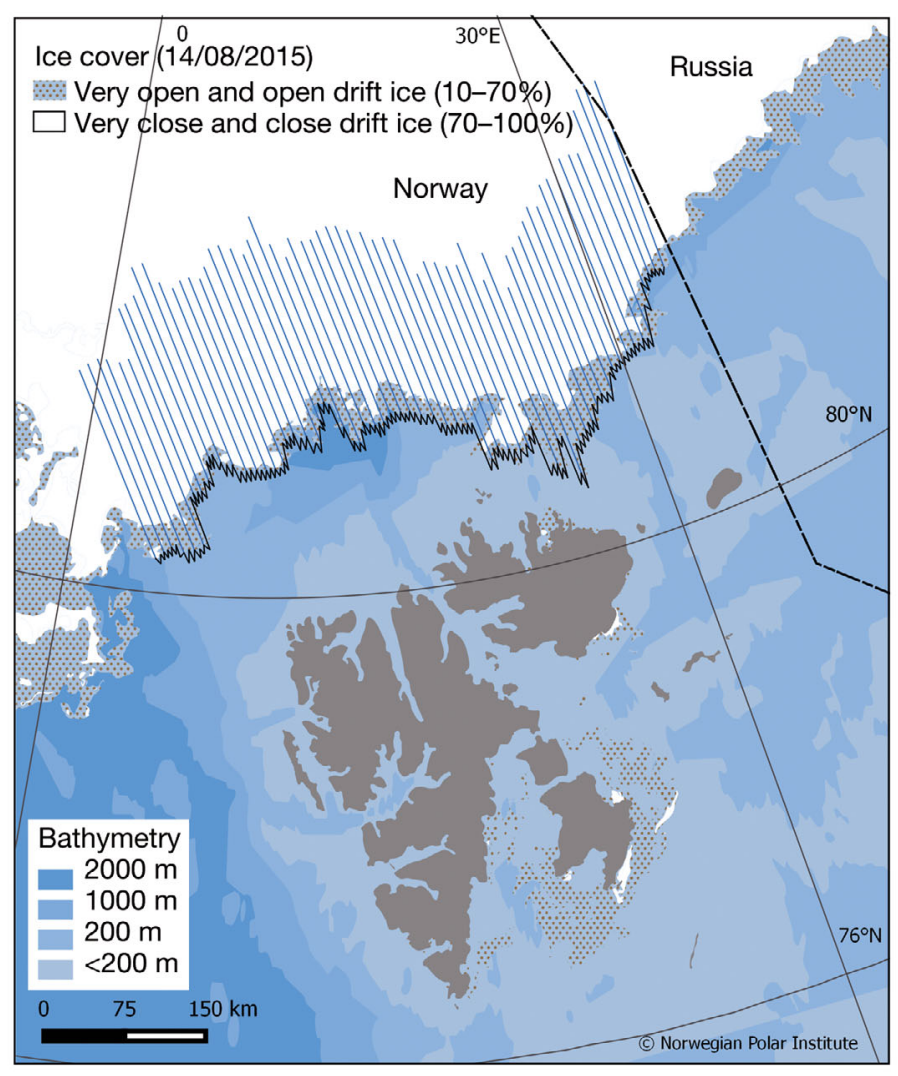

Fig. 1. Design of survey(s), Svalbard, Norway. The Svalbard Archipelago land areas are portrayed in grey. The ice data are for 14 August 2015 and are derived from daily sea ice charts from the Norwegian Meteorological Institute's Ice Service (www.met.no). Blue straight lines represent planned helicopter transects and the black zigzag lines represent planned ship transects

edge toward open water when the visibility was sufficient (visibility $>2 \mathrm{nmi}$ ).

Cetacean sightings (and polar bears, which are reported elsewhere) from both platform types were noted on a PC using the 'Seabirds and Sea Mammals at Sea Registration Program', adapted specifically to these surveys (V. Bakken \& F. Mehlum unpubl.), as well as each sighting being recorded physically in a notebook. For the ship survey(s), observations were done from the bridge(s) (10 $\mathrm{m}$ for the 'RV Lance' and $18 \mathrm{~m}$ for the 'KV Svalbard') by a team of 2 (non-isolated) observers. Six people rotated in $6 \mathrm{~h}$ shifts to achieve 24/7 coverage. Each observer focused on one side of the transect line, with some overlap occurring between the 2 observers' search areas over the trackline. Each data record included the position of the platform when the sighting occurred, the estimated distance and angle of the observed animal relative to the ship, as well as the species, the number of individuals per sighting and ice concentration levels. For the helicopter survey, 4 observers (including the pilot) acted as a single observation team, with rotation between 2 complete flight teams taking place at least every $6 \mathrm{~h}$. The pilot was considered a full observer since the helicopter, travelling slowly, was flown visually (not by instruments) along the straight transects. The 2 observers in the front seats focused on detections on or close to the transect line in front of the helicopter (i.e. unobstructed view), while the 2 rear observers focused to each side of the helicopter farther away from the transect line, but with some overlap with the front observers' search areas. Every time an animal was detected, the helicopter went 'off effort' to the place where the animal had first been seen, and positional data was taken according to Marques et al. (2006). At this time, the species was confirmed and the data was recorded on the PC and in the notebook. The helicopter then returned to being 'on effort' and the transect continued from where the helicopter had left off. Besides position and species, for each sightings the number of individuals and ice concentration levels were recorded.

Sightings of whales along the transect lines were used to estimate abundance following conventional line transect distance sampling (e.g. Buckland et al. 2001). The perpendicular distance from the transect to each observed animal (or group, which included multiple, closely clustered animals in all cases) was used to model a detection function representing the probability of a detection, given its distance from the transect line. These perpendicular distances from the transect line were calculated in QGIS 2.10 (http:// qgis.org/en/site/). The modelling of the detection function was implemented independently for each species. Classical key parametric models (half-normal, uniform and hazard rate) with up to 2 cosine adjustment terms were fitted with the software Distance 7.0 (Buckland et al. 2001). The best models were selected according to the AIC values (Buckland et al. 2001) and these models were used to estimate the abundance of each species in the survey area (i.e. raw abundance estimates). Because the sample size was small, no truncation of the data was done when modelling the detection function. Additionally, to decrease the influence of the detection function fitting on the results, no attempt was made to correct the observations for potential sample size bias (observed mean group size was used as the estimate of mean group size). To correct the abundance of 
each species for availability biases (i.e. availabilitycorrected abundance estimates), the proportion of time spent at the surface estimated by previous tracking studies was used. Surface availabilities and their corresponding coefficients of variation, $0.2(\mathrm{CV}=0.19$, $\mathrm{n}=3)$ and $0.316(\mathrm{CV}=0.053, \mathrm{n}=9)$, were used to correct the abundance of bowhead whales and narwhals, respectively, based on studies by Hansen et al. (2012) in Greenland and Westdal et al. (2013) in the Eastern Canadian Arctic. No correction factors were required for white whales in this study (see 'Results'). The survey area was calculated by connecting all the extremities of the transect lines, as was done in Hansen et al. (2012).

\section{Data from the MMSD}

All cetacean sighting records from the Svalbard area for the study period were extracted from the MMSD to give context to the survey data. Sources of these data include the Norwegian Coast Guard, the Governor of Svalbard's field inspectors, the annual joint Russian-Norwegian Ecosystem Survey with dedicated marine mammal observers (Michalsen et al. 2013), reports from research cruises (principally the Norwegian Polar Institute and the Institute of Marine Research, but also others) and marine tourist expedition operators. These data are quality-checked with all rare sightings being confirmed via photographic evidence, which is checked by regional cetacean experts. Data records in MMSD include vessel, expedition leader (or the person responsible for the reporting), date, hour, latitude and longitude of the sighting as well as the species, the number of individuals and optional comments. In 2015, the MMSD also received all cetacean sightings made along the coasts and in the fjords of the Svalbard Archipelago from a near-shore helicopter-based survey (Eurocopter AS350 Ecureuil helicopter) targeting polar bears on land strata and on coastal ice, in addition to off-effort sightings made by the 2 ships and the helicopter involved in the ice surveys being reported herein, when they were in transit to and from the ice.

\section{RESULTS}

Survey effort included 65 ship zigzag transect lines and 56 helicopter transect lines, corresponding to 599 and $7830 \mathrm{~km}$ of coverage, respectively (Fig. 2). During the ship survey(s), no whales were observed. During the helicopter survey, there were 15 bowhead whale sightings (27 ind.) and 11 narwhal sightings (58 ind.) (Table 1, Fig. 2); no white whales were seen on effort. There was clear spatial segregation in the sightings of the 2 observed species. All of the bowhead whale sightings occurred close to the ice edge in areas with medium ice concentrations (50-80\%), while the narwhal sightings were predominantly deep into the ice at higher latitudes and in areas with higher ice concentrations (80-100\%) (Fig. 2). An offeffort sighting of 2 bowhead whales along the iceedge was made from the ship, and 2 additional offeffort narwhal sightings (3 ind.) occurred from the helicopter in areas with heavy ice-concentrations. These sightings occurred while on transit between transect lines and hence are not used in the abundance estimates, but are included in the MMSD records in Table 1 and Fig. 2.

Only sightings and effort from the helicopter survey were used to estimate abundance. The total area surveyed by the helicopter was estimated to be 52919 km² $^{2}$ (i.e. pink area in Fig. 2). Since no white whales were observed during the line transects, abundance estimates were calculated only for bowhead whales and narwhals. The encounter rates per kilometer of helicopter transect line were 1.9158 $10^{-4}(\mathrm{CV}=0.38)$ for bowhead whales and 1.4049 $10^{-4}(\mathrm{CV}=0.28)$ for narwhals. Mean group sizes were $1.8(\mathrm{CV}=0.19)$ for bowhead whales and 5.27 $(\mathrm{CV}=0.41)$ for narwhals. The distribution of perpendicular sighting distances for these 2 species, as well as their detection functions, are shown in Fig. 3. Candidate models considered for the detection function for the bowhead whale and the narwhal sightings during the survey are summarized in Table 2. Given the small differences in AIC for the top 4 models, as well as the low number of sightings of each species, the most conservative, minimum estimates provided by these 4 models (in bold in Table 2) were considered. This resulted in raw and availability-corrected estimates for bowhead whales of $69(\mathrm{CV}=0.449,95 \% \mathrm{CI} 29-160)$ and $343(\mathrm{CV}=$ 0.488, 95\% CI 136-862) individuals, respectively, and raw and availability-corrected estimates for narwhals of 268 (CV $=0.497,95 \%$ CI 101-711) and $837(\mathrm{CV}=0.501,95 \%$ CI 314-2233) (Table 2) individuals, respectively.

The MMSD cetacean data for August 2015 consisted of 147 sightings, totaling 696 individuals of 10 species. Of these sightings, 4 were sightings of bowhead whales ( 7 ind.), 2 were of narwhals ( 3 ind.) and 13 were of white whales (totaling more than 370 ind.). The number of sightings extracted from this database as well as the number of individuals per 


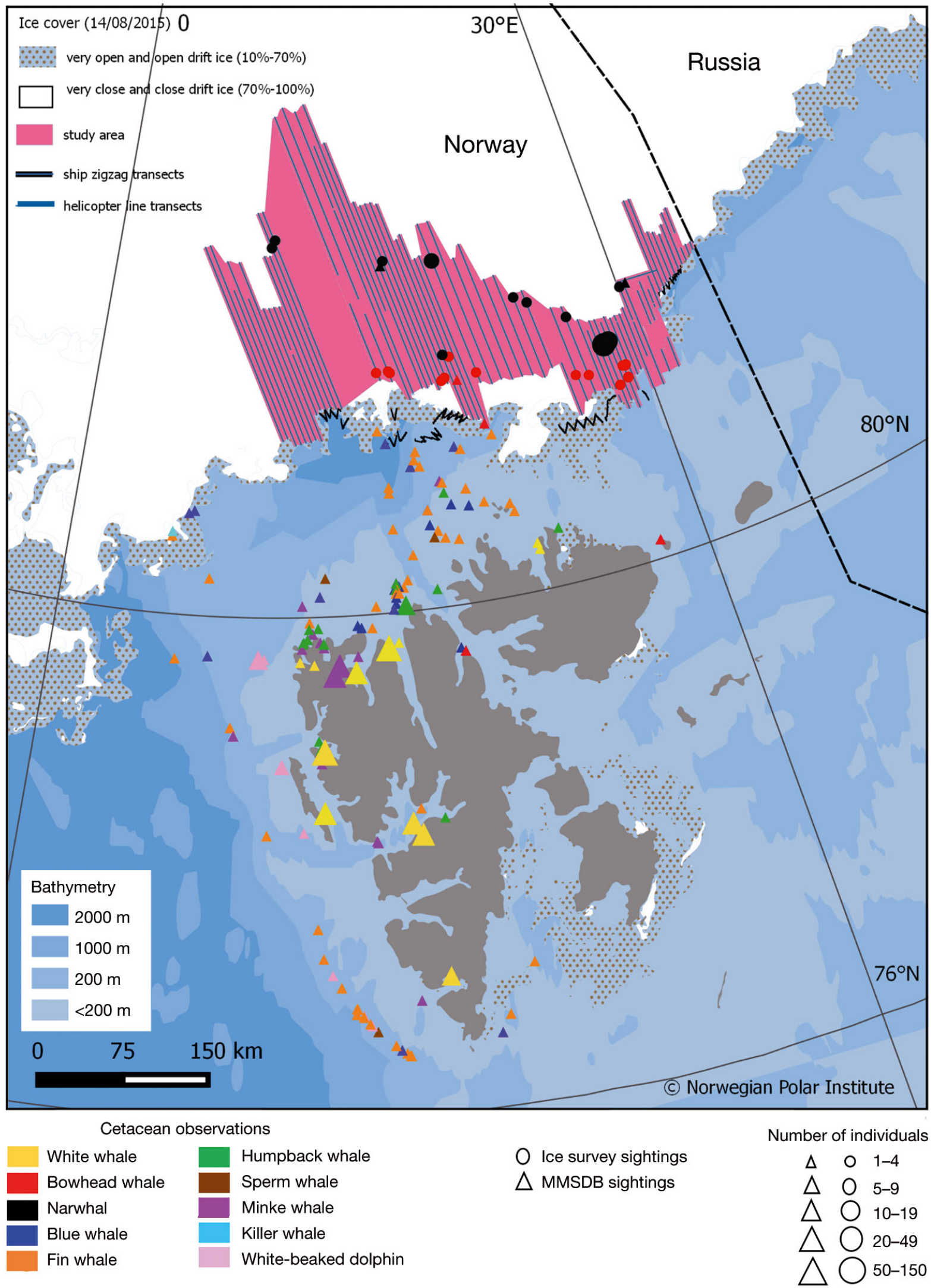

Fig. 2. Occurrence and distribution of Arctic resident and seasonally occurring cetaceans during late summer 2015 in Svalbard, Norway. The Svalbard Archipelago land areas are portrayed in grey. The ice data are for 14 August 2015 and are derived from daily sea ice charts from Norwegian Meteorological Institute's Ice Service (www.met.no). Straight lines and zigzag lines represent realized helicopter and ships transects respectively, conducted during the surveys. Purple shading represents the study area covered by the helicopter, for which abundance estimates were derived. Cetacean observations outside the survey study area are from the Norwegian Polar Institute's Marine Mammal Sighting Database from the same time period as the survey 
Table 1. Arctic resident and seasonally occurring cetacean sightings in August 2015 in the Svalbard area. The top section of the table represents sightings recorded during the marginal ice zone (MIZ) helicopter survey. No cetaceans were observed during the ship survey. The lower section of the table represents sightings extracted from the Norwegian Polar Institute's Marine Mammal Sightings Database (MMSD). obs: observation

\begin{tabular}{|c|c|c|c|c|c|c|c|c|c|c|c|}
\hline Sighting details & $\begin{array}{l}\text { Nar- } \\
\text { whal }\end{array}$ & $\begin{array}{l}\text { Bow- } \\
\text { head } \\
\text { whale }\end{array}$ & $\begin{array}{l}\text { White } \\
\text { whale }\end{array}$ & $\begin{array}{c}\text { Blue } \\
\text { whale }\end{array}$ & $\begin{array}{c}\text { Fin } \\
\text { whale }\end{array}$ & $\begin{array}{l}\text { Minke } \\
\text { whale }\end{array}$ & $\begin{array}{c}\text { Hump- } \\
\text { back } \\
\text { whale }\end{array}$ & $\begin{array}{l}\text { Killer } \\
\text { whale }\end{array}$ & $\begin{array}{l}\text { Sperm } \\
\text { whale }\end{array}$ & $\begin{array}{l}\text { White- } \\
\text { beaked } \\
\text { dolphin }\end{array}$ & Total \\
\hline \multicolumn{12}{|l|}{ MIZ Survey (helicopter) } \\
\hline No. of observations & 11 & 15 & 0 & 0 & 0 & 0 & 0 & 0 & 0 & 0 & 26 \\
\hline No. of ind. & 58 & 27 & 0 & 0 & 0 & 0 & 0 & 0 & 0 & 0 & 85 \\
\hline Mean no. of ind. per obs. & 5.27 & 1.80 & 0.00 & 0.00 & 0.00 & 0.00 & 0.00 & 0.00 & 0.00 & 0.00 & 3.27 \\
\hline \multicolumn{12}{|l|}{ MMSD (helicopter and ships) } \\
\hline No. of observations & 2 & 4 & 13 & 23 & 56 & 16 & 16 & 1 & 3 & 13 & 147 \\
\hline No. of ind. & 3 & 7 & 376 & 32 & 88 & 76 & 30 & 2 & 3 & 79 & 696 \\
\hline Mean no. of ind. per obs. & 1.50 & 1.75 & 28.92 & 1.39 & 1.57 & 4.75 & 1.88 & 2.00 & 1.00 & 6.08 & 4.73 \\
\hline
\end{tabular}

sighting are summarized in Table 1. Besides the offeffort bowhead whale and narwhal sightings during the survey (detailed previously) 3 additional bowhead whale sightings, totaling 5 individuals, were reported to $\mathrm{MMSD}_{\text {; }}$ one in the ice and 2 from open water areas. White whales were generally observed close to the coastlines and inside fjords (Fig. 2). The majority of the sightings of seasonally occurring cetaceans occurred along the continental shelf breaks (where the continental shelf ends and the slope to deep water begins), particularly to the west and north of Spitsbergen. However, several sightings of seasonally occurring cetaceans were also made inside fjords (Fig. 2). The most frequently observed baleen whale species were fin whales Balaenoptera physalus, blue whales, humpback whales Megaptera novaeangliae and minke whales $B$. acutorostrata. Whitebeaked dolphins Lagenorhynchus albirostris were the most commonly sighted odontocetes, while only one killer whale Orcinus orca sighting was reported to MMSD in 2015 (Fig. 2). Blue whales, fin whales, sperm whales Physeter macrocephalu) and whitebeaked dolphins were mainly observed offshore along the shelf margins, while minke whales and humpback whales were more commonly observed in the fjords (Fig. 2).

\section{DISCUSSION}

Assessment of the consequences of climate change on Arctic resident cetaceans is complicated by the lack of knowledge regarding their abundance and distribution and their regional ecologies (Kovacs et al. 2011b, Reeves et al. 2014). The present study provides the first abundance estimates for bowhead whales and narwhals in a segment of the Norwegian Arctic, north of the Svalbard Archipelago, and also provides unique insights regarding the late summer spatial distribution of these species in relation to sea ice in this area and the broader cetacean community occupying the region.

\section{Bowhead whale distribution and abundance}

Bowhead whales were taken to the brink of extinction in Svalbard by whaling that started upon the discovery of the archipelago. The so-called

Spitsbergen stock, which extends
Fig. 3. Probability of detection during the helicopter survey for (A) bowhead whales and (B) narwhals. The histograms represent the distribution of sighting distances and the red lines represent the corresponding detection probabilities based on a uniform (with 1 adjustment term) model for bowhead whales and a uniform (without adjustment terms) model for narwhals 


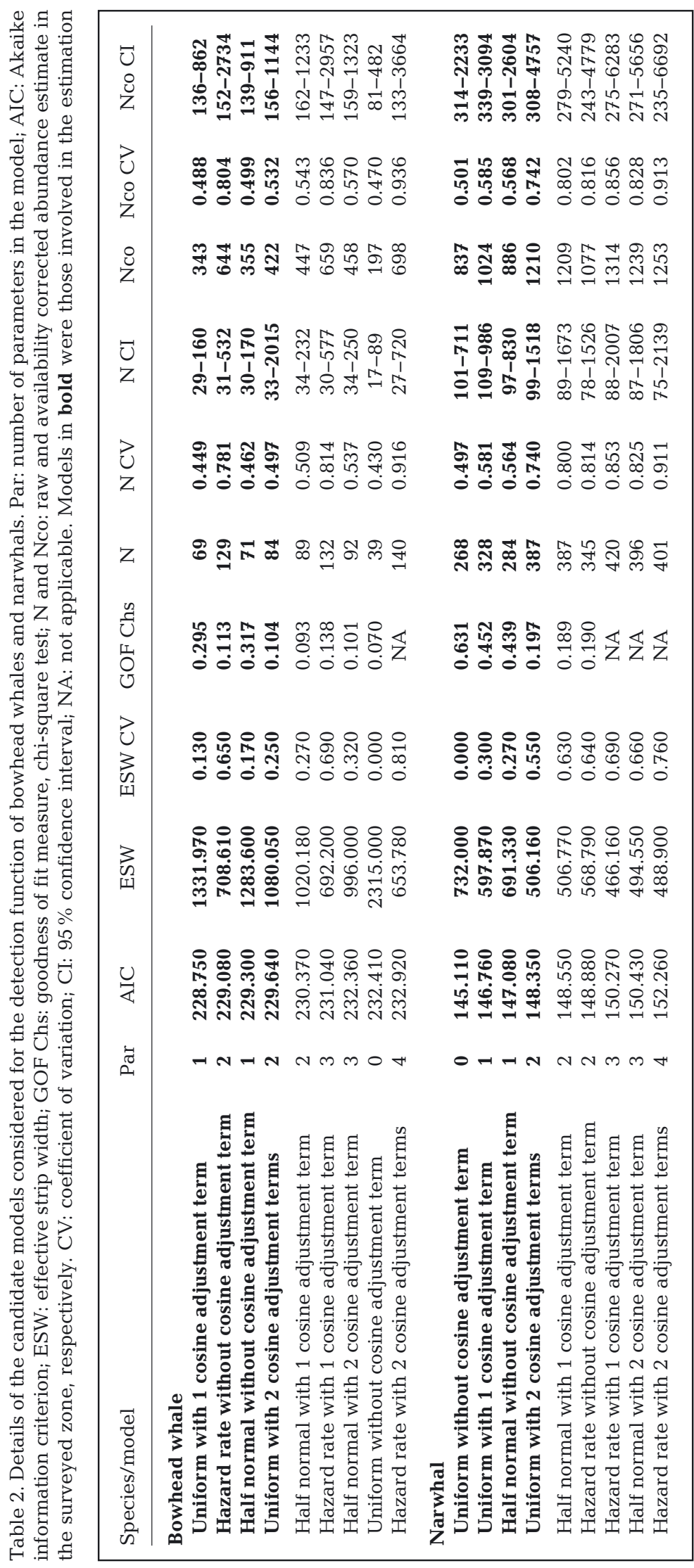

from east Greenland across the northern Barents Sea to Franz Josef Land (HeideJørgensen et al. 2006, Laidre et al. 2015) has been estimated to have numbered around 52500 (with a plausible range of 25000 to 100000 ; Allen \& Keay 2006) before commercial whaling commenced in 1611. Despite being protected from harvesting for many decades (Reilly et al. 2012), this population was assumed to consist of only some few 10 s of individuals (Wiig et al. 2010) at the start of the current century. However, during the last decade a few studies collectively suggest that some level of recovery is taking place. A survey conducted in northeast Greenland by Boertmann et al. (2015) suggested that more than 100 bowhead whales $(\mathrm{CV}=$ 0.61, 95\% CI 32-329) might have occupied the Northeast Water Polynya, in northeast Greenland in 2009. Additionally, passive acoustic monitoring in the Fram Strait, close to the east Greenland shelf $\left(78^{\circ} 49.9^{\prime} \mathrm{N}, 4^{\circ} 59.1^{\prime} \mathrm{W}\right)$, has demonstrated the year-round presence of bowhead whales in this region, reporting calling rates that suggest numbers of animals in excess of the assumed '10s' (Moore et al. 2012, Stafford et al. 2012). However, these optimistic signs are tempered by research expeditions in search of bowhead whales conducted in 2006, 2007, 2008 and 2010 between east Greenland and Svalbard, as well as a research expedition in search of polar bears conducted in the MIZ zone north of Svalbard in the summer of 2004 that found very few bowhead whales (Wiig et al. 2007, 2010, Kovacs et al. 2011a, Lydersen et al. 2012, J. Aars pers. obs.). In the present study, both ship transects along the MIZ and helicopter transects that extended deep into the ice north of Svalbard were conducted in search of Arctic resident, ice-associated whales (and polar bears). No sightings were made of bowhead whales during the ship transect lines. The single sighting of 2 bowhead whales seen from the ship during a transit phase is not included in the population estimate. However, the 15 sightings (27 ind.) made during the aerial survey, were used to assess abundance of bowhead whale in the study area. The sample 
size achieved falls below the minimum recommended sample size for the application of distance sampling detection function models, and in hindsight, use of a strip transect method (a uniform model with fixed right truncation and no adjustment terms) would have likely produced a more robust estimate. However, the line transect was the methodology employed to conduct this survey (with heavy observer focus on the 0-line), so the models were run accordingly, and a conservative distance sampling line-transect approach was used to calculate the estimates. Line methods are, all basically, quite conservative since they lead to higher confidence intervals. The most conservative model output suggests an availability corrected estimate of 343 (CV $=0.488$, $95 \%$ CI 136-862) bowhead whales in the area covered by the survey. No data were available from this bowhead whale population to estimate sighting availability (proportion of time on the surface), so data from a neighboring population to the west of Greenland were used to calculate an availability correction factor in the current study (Hansen et al. 2012). Hansen et al.'s (2012) results are based on only 4 animals tagged during spring in Disko Bay, so these data might not accurately represent the behavior of animals in the Spitsbergen population in late summer. However, knowing that a proportion of the animals are submersed at any given point in time, availability is clearly important to consider. These combined limitations dictate that the survey results reported herein must be viewed in a precautionary manner until more data become available. Nonetheless, the present study does strongly support the suggestion that the size of the Spitsbergen stock likely numbers in the 100s rather than in the 10s, especially considering the small fraction of this stock's summer range that was covered by the survey.

A helicopter survey (e.g. focused on polar bears, Aars et al. 2009) conducted in 2004 in the same area, season and conditions as the current survey (i.e. summer and deep into the ice north of Svalbard), saw only 1 bowhead whale (J. Aars pers. obs.) in contrast to the 15 sightings involving 27 individuals in this survey. This suggests that animals might have migrated into this area from other places over the past decade (Boertmann et al. 2015), facilitated by the reduction in sea ice (see Heide-Jørgensen et al. 2007) and increasing trends in some populations (Moore 2016), or alternatively, and most likely, this suggests a patchy, variable distribution of the animals in this stock. But, further studies are needed to confirm the degree of inter- and intra-annual variability in distribution.
Bowhead whales from this stock were historically plentiful in the fjords of Svalbard. These animals in the fjords were the first to be harvested by whalers in the 16th century. After they were depleted, the whaling moved offshore and within a few centuries these animals were also hunted to near extinction. In this study, most bowhead whale sightings occurred close to the ice edge in areas with ice concentrations $\geq 50 \%$ cover. If part of the stock historically occupied an icecovered habitat, this fraction of the stock would not have been available to the hunters. Boertmann et al. (2015) made similar conclusions regarding the animals surveyed in the Northeast Water Polynya in 2009; this area would not have been available for the early whalers because the polynya is surrounded by heavy pack ice. In addition, the most intense vocal behavior of bowhead whales from this stock has been recorded in heavy ice (Stafford et al. 2012). Therefore, it seems that bowhead whales from the Spitsbergen stock frequently occupy ice habitats, even if animals do make excursions into open water (see Lydersen et al. 2012).

The presence of killer whales might be another reason why the bowhead whales occupy areas that are at least partly ice-covered (Ferguson et al. 2010a). However, there is little information regarding the abundance or distribution of killer whales in the Svalbard area. Nonetheless, they are not uncommon on the west side of Svalbard (Øien 1988) and have been observed north of $80^{\circ} \mathrm{N}$ in the same areas, and at the same times, as bowhead whales were observed in both the 2006 and 2010 ship survey efforts in Svalbard (Lydersen et al. 2012). During the period of the current study, there was only a single sighting of 2 killer whales reported to the MMSD, but interestingly they were at the southern edge of the ice north of Svalbard (see Fig. 2). Reduced sea ice cover is expected to result in an increase in killer whale predation on all 3 Arctic resident species of cetaceans in Svalbard, as has already been documented for Hudson Bay (Ferguson et al. 2010b, 2012).

\section{Narwhal distribution and abundance}

Very little is known about narwhals in the Svalbard area. They were not a targeted species during historical commercial whaling, which implies that they were not routinely available to the whalers. Only a few animals are registered as having been harvested in the region (Gjertz 1991). Pods in the 100s have been sighted in fjords in Nordaustlandet, in the northeast corner of Svalbard (K. M. Kovacs pers. obs., 
C. Lydersen pers. obs.), but this species is only rarely reported to the MMSD. They were not reported outside the survey area during the period of the present survey. The narwhals in Svalbard are likely part of a population that stretches from East Greenland, eastwards to Svalbard and beyond into the Russian Arctic (Heide-Jørgensen 2002). Except for some few studies (Palsbøll et al. 1997, Heide-Jørgensen et al. 2010, 2015), not much is known about the population size or genetic associations of narwhals from this vast distributional area. A survey covering a small part of this population's range, around the hunting grounds in East Greenland, estimated that there were about 6450 individuals in this stock $(\mathrm{CV}=0.51,95 \% \mathrm{CI}$ 2505-16575; Heide-Jørgensen et al. 2010). The most conservative model output suggests an availability corrected estimate of 837 (CV $=0.501,95 \%$ CI 3142233) narwhals in the area covered by the present survey. Similar to the situation for the bowhead whales, the number of narwhal sightings (11 sightings involving 58 individuals) was too low to model the detection function reliably, but a distance sampling line-transect approach was utilized in this study for this species as well for the same reasons. A uniform function without adjustment terms was used to calculate abundance. While this model is unlikely to be realistic, since it is unreasonable to expect a flat detection function, it does provide a minimal, conservative value for abundance. In addition, as for bowhead whales, lacking a better option, availability estimates from another time and place (August 2006 and 2007, Repulse Bay, Nunavut area), based on a very small sample size ( $\mathrm{n}=9$, cf. Westdal et al. 2013) were used to calculate the proportion of animals expected to be at the surface at a given time, which makes reported values tentative at best.

Most information concerning narwhal spatial ecology is derived from studies conducted on the Baffin Bay population (Heide-Jørgensen \& Dietz 1995, Laidre et al. 2003). There, narwhals spend the winter deep into ice-covered habitats along the continental slope, where they regularly dive to below $1500 \mathrm{~m}$. In summer, animals in this population occupy ice-free shallow bays and fjords. During a tracking study of narwhals from Svalbard during the summer season, the 3 tagged individuals seemed to follow patterns similar to animals in the Baffin Bay population; they were caught in ice-free waters in a fjord and they spent most of the tracking period in open water, diving to depths up to $500 \mathrm{~m}$ in a trough east of Svalbard (Lydersen et al. 2007). However, in the present study, the narwhals were observed deep into the ice north of Svalbard, mainly in waters with depths exceeding
$2000 \mathrm{~m}$, in habitats similar to those where the Baffin Bay population spends the winter. It is noteworthy that narwhals were observed along the northern limit of the area covered by the survey (Fig. 2) and thus, the abundance estimate from the survey is almost certainly negatively biased. Similar to the bowhead whales seen within the study, all the sightings of narwhals were recorded from the helicopter; no narwhals were seen from the ship.

It is important to note that most of the sightings of bowhead whales and narwhals during this study were seen from the helicopter (Table 1). Although occasional sightings are made of these 2 species in open water, the survey suggests that these species preferentially occupy areas of ice concentration higher than that normally traversed by ships, which may explain why these whales are so rarely reported to the MMSD. However, even though 2 icebreaking ships were used in the current survey effort, no whales were observed from the ships. Ship noise might cause avoidance behavior, though it must be noted that the single whale tagged in this stock (Lydersen et al. 2012) was tagged directly from the 'RV Lance', because ice-cover was too dense to launch a smaller vessel. However, the distribution of the whales seen in this survey highlights the necessity of using aircraft, rather than ships, to survey Arctic resident species in ice-covered areas.

\section{White whale distribution}

Although surveys have never been conducted to determine white whale abundance in Svalbard, it seems clear that this species is by far the most numerous Arctic resident whale within the region (Kovacs \& Lydersen 2006). This species was hunted in a coastal fishery up until the mid-1960s, at which time they became protected because it was assumed that they were becoming depleted, given the high catch numbers (Lønø \& Øynes 1961, Gjertz \& Wiig 1994). They are routinely reported to the MMSD throughout the period when there is light in Svalbard (i.e. outside the polar night). Previous satellite tracking of white whales in Svalbard has shown that animals captured in shore-set nets remain extremely coastal during summer and autumn, spending most of their time close to tidewater glacier fronts (Lydersen et al. 2001). When they move from one glacier front to another, they do so in a directed and rapid manner, very close to shore (Lydersen et al. 2001). The glacier fronts provide the whales with concentrations of food (Dahl et al. 2000, Lydersen et al. 2001, 2014) and a 
source of fresh water that is suggested to be advantageous for the whales' annual molting process (St Aubin et al. 1990, Boily 1995). In places other than Svalbard, white whales gather in huge concentrations in river estuaries to molt (Finley 1982, Hansen 1987). However, in Svalbard there are no rivers deep enough to accommodate the whales, but melt water from the glaciers represents a predictable source of freshwater in sufficiently deep areas. When sea ice formed in the late autumn during the tracking study, the whales were pushed offshore, but they remained in the same general areas where they spent the summer in ice concentrations often higher than $90 \%$ (Lydersen et al. 2002, C. Lydersen \& K. M. Kovacs unpubl. data). White whales were not observed along the transect lines in the current study, either from the ship(s) or the helicopter. This was unexpected given that, in other places in the Arctic, white whales are highly ice associated during this time of the year and routinely occupy ice edges in the Canadian Arctic and in Alaska (Martin et al. 1993, Richard et al. 2001, Suydam et al. 2001). However, as is the norm, white whales were seen in coastal areas during the survey period. Thirteen sightings of this species were reported to the MMSD during the study period, totaling at least 376 individuals. All of these sightings took place close to the coast; none were reported from offshore areas.

\section{Distribution of seasonally resident cetaceans}

Blue whale and fin whale sightings dominated the baleen whale sightings reported to the MMSD. Both of these species were observed mainly along the shelf breaks west and north of Svalbard (Fig. 2). Sighting rates of these 2 species are increasing, particularly inside the fjords of the archipelago, where they were never seen previously, coinciding with an increase of intrusion of Atlantic Water with associated Atlantic prey into these areas (Pavlov et al. 2013, Fossheim et al. 2015). Humpback whales and minke whales have a tendency to concentrate in coastal shelf areas in many areas of the world (Martin 1990). This is certainly the case in the Svalbard area, where they are routinely seen in fjords or along the coastal shelf north of Svalbard from late spring and through the summer into the early autumn (Kovacs \& Lydersen 2006). During the study period, 16 minke whale sightings and 16 humpback whale sightings were reported to the MMSD, all within shelf waters. Thirteen white-beaked dolphins sightings were also reported during the study period, mainly along the shelf break west of Svalbard. Only 3 sightings of sperm whales were recorded; however, this is a deep-diving whale that spends most of its time offshore in areas where few observers go.

The data from our survey, combined with the data from the MMSD, suggests little spatial overlap between seasonally occurring cetaceans and the 3 Arctic resident cetaceans; similar findings have been previously reported by Laidre \& Heide-Jørgensen (2012) from West Greenland. The bowhead whales and narwhals in Svalbard occurred deeper into the ice and the white whales occurred closer to shore than any of the seasonally occurring species.

\section{CONCLUSIONS}

This study has produced the first estimate of abundance of bowhead whales and narwhals in a sector of the Norwegian Arctic north of Svalbard and has documented a high affiliation of these 2 species with sea ice during late summer in this region. The distribution of these species has also been explored in the context of the spatial distribution of other cetacean species in the archipelago during summer; little overlap occurred between the resident Arctic species and the seasonally occurring species. Although little is known about how transient the populations of these 2 resident species are within the MIZ north of the Svalbard Archipelago, the results of the survey suggest that it is reasonable to assume that the Spitsbergen population of bowhead whales likely consists of at least several 100s of animals, and that the narwhal population might be in the low 1000s. Lack of comparative data from other years limits interpretation of the findings in relation to the potential impacts of the changes in ice extent and its seasonal availability that have taken place in the region in recent decades (Laidre et al. 2015). However, this study represents a first essential step towards this goal, which is valuable for conservation and management purposes in a rapidly changing Arctic. This study highlights that the sea ice represents an important habitat for these species in late summer in this region and clearly documents that aircraft are required to conduct surveys of bowhead whales and narwhals in the Svalbard area because of their potential occurrence deep into the ice. Given the recent rapid declines in sea ice in the Norwegian Arctic and the forecasts of continued declines, as well as the rudimentary state of knowledge regarding the population ecology of bowhead whales and narwhals in this area, routine monitoring programmes should be developed. White whale sur- 
veys in the Svalbard area will require a coastal survey effort independent of the other 2 species, given the remarkable spatial separation of these species in this region.

Acknowledgements. This study was financed by the Norwegian Research Council ICE whales grant (No. 244488/E10), The Foreign Ministry of Norway (Norwegian-Russian programme), WWF Sweden and the Norwegian Polar Institute. We thank all the colleagues involved in this survey, with special acknowledgement of the invaluable contribution of Magnus Andersen, Karen Lone, Nick Cobbing for the helicopter survey and Kine Øren, Luke Storrie, Semyon Bodrov, Francina Becker and Sabrina Tartu for the ship survey. We also thank the Airlift flight crew as well as the crews of 'RV Lance' and 'KV Svalbard' (Norwegian Coastguard) for their support in conducting this work and AECO (Association of Arctic Expedition Cruise Operators) for their on-going support of, and contributions to, the MMSD. T.A.M. was supported in part by CEAUL (funded by FCT - Fundação para a Ciência e a Tecnologia, Portugal, through the project UID/MAT/00006/2013).

\section{LITERATURE CITED}

Aars J, Marques TA, Buckland ST, Andersen M, Belikov S, Boltunov A, Wiig $\varnothing$ (2009) Estimating the Barents Sea polar bear subpopulation size. Mar Mamm Sci 25:35-52

Allen RC, Keay I (2006) Bowhead whales in the eastern Arctic, 1611-1911: population reconstruction with historical whaling records. Environ Hist 12:89-113

Bailleul F, Vacquie-Garcia J, Guinet C (2015) Dissolved oxygen sensor in animal-borne instruments: an innovation for monitoring the health of oceans and investigating the functioning of marine ecosystems. PLOS ONE 10: e0132681

Barber DG, Iacozza J (2004) Historical analysis of sea ice conditions in M'Clintock Channel and the Gulf of Boothia, Nunavut: implications for ringed seal and polar bear habitat. Arctic 57:1-14

Boertmann D, Kyhn LA, Witting L, Heide-Jørgensen MP (2015) A hidden getaway for bowhead whales in the Greenland Sea. Polar Biol 38:1315-1319

* Boily P (1995) Theoretical heat flux in water and habitat selection of phocid seals and beluga whales during annual moult. J Theor Biol 172:235-244

Buckland ST, Anderson DR, Burnham KP, Laake JL, Borchers DL, Thomas L (2001) Introduction to distance sampling. Oxford University Press, Oxford

Dahl TM, Lydersen C, Kovacs KM, Falk-Petersen S, Sargent J, Gjertz I, Gulliksen B (2000) Fatty acid composition of the blubber in white whales (Delphinapterus leucas). Polar Biol 23:401-409

Ferguson SH, Dueck L, Loseto LL, Luque SP (2010a) Bowhead whale Balaena mysticetus seasonal selection of sea ice. Mar Ecol Prog Ser 411:285-297

Ferguson SH, Loseto LL, Mallory ML (2010b) A little less Arctic. Top predators in the world's largest northern inland sea, Hudson Bay. Springer, New York, NY

Ferguson SH, Kingsley MCS, Higdon JW (2012) Killer whale (Orcinus orca) predation in a multi-prey system. Popul Ecol 54:31-41
Finley KJ (1982) The estuarine habitat of the beluga or white whale, Delphinapterus leucas. Cetus 4:4-5

Fossheim M, Primicerio R, Johannesen E, Ingvaldsen R, Aschan MM, Dolgov AV (2015) Recent warming leads to a rapid borealization of fish communities in the Arctic. Nat Clim Change 5:673-677

*Gjertz I (1991) The narwhal, Monodon monoceros, in the Norwegian high Arctic. Mar Mamm Sci 7:402-408

Gjertz I, Wiig O (1994) Distribution and catch of white whales (Delphinapterus leucas) at Svalbard. Medd Gronl Biosci 39:93-97

Hansen SE (1987) White whale (Delphinapterus leucas) distribution and abundance in relation to water temperature, salinity, and turbidity in the Churchill River estuary. MSc Thesis, Laurentian University, Sudbury

Hansen RG, Heide-Jørgensen MP, Laidre KR (2012) Recent abundance of bowhead whales in Isabella Bay, Canada. J Cetacean Res Manag 12:317-319

*Harington CR (2008) The evolution of Arctic marine mammals. Ecol Appl 18:S23-S40

Heide-Jørgensen MP (2002) Narwhal Monodon monoceros. In: Perrin WF, Würsig B, Theweissen JGM (eds) Encyclopedia of marine mammals. Academic Press, London, p 783-787

Heide-Jørgensen MP, Dietz R (1995) Some characteristics of narwhal, Monodon monoceros, diving behaviour in Baffin Bay. Can J Zool 73:2120-2132

* Heide-Jørgensen MP, Laidre KL (2004) Declining extent of openwater refugia for top predators in Baffin Bay and adjacent waters. Ambio 33:487-494

*Heide-Jørgensen MP, Laidre KL, Jensen MV, Dueck L, Postma LD (2006) Dissolving stock discreteness with satellite tracking: bowhead whales in Baffin Bay. Mar Mamm Sci 22:34-45

*Heide-Jørgensen MP, Laidre KL, Borchers F, Samarra F, Stern H (2007) Increasing abundance of bowhead whales in West Greenland. Biol Lett 3:577-580

*Heide-Jørgensen MP, Laidre KL, Burt ML, Borchers DL, and others (2010) Abundance of narwhals (Monodon monoceros) on the hunting grounds in Greenland. J Mammal 91:1135-1151

*Heide-Jørgensen MP, Nielsen NH, Hansen RG, Schmidt HC, Blackwell SB, Jørgensen OA (2015) The predictable narwhal: satellite tracking shows behavioural similarities between isolated subpopulations. J Zool (Lond) 297: $54-65$

IPCC (2013) Summary for policymakers. In: Stocker TF, Qin D, Plattner GK, Tignor M and others (eds) Climate Change 2013: the physical science basis. Contribution of Working Group I to the Fifth Assessment Report of the Intergovernmental Panel on Climate Change, Cambridge University Press, Cambridge

Jefferson TA, Karkzmarski L, Laidre K, O'Corry-Crowe G and others (2012a) Delphinapterus leucas. The IUCN Red List of Threatened Species:e.T6335A17690692

Jefferson TA, Karkzmarski L, Laidre K, O'Corry-Crowe G and others (2012b) Monodon monoceros. The IUCN Red List of Threatened Species:e.T13704A17691711

Joos F, Plattner GK, Stocker TF, Körtzinger A, Wallace DWR (2003) Trends in marine dissolved oxygen: implications for ocean circulation changes and the carbon budget. Eos Trans AGU 84:197-201

Kovacs KM, Lydersen C (2006) Birds and mammals of Svalbard. Norwegian Polar Institute, Tromsø

Kovacs KM, Lydersen C (2008) Climate change impacts on 
seals and whales in the North Atlantic Arctic and adjacent shelf seas. Sci Prog 91:117-150

Kovacs KM, Biuw M, Nøst OA, Dodd P and others (2011a) Seals used as 'research assistants' in the polar oceans. In: Orheim O, Ulstein K (eds) International polar year 20072008: The Norwegian contribution. Research Council of Norway, Oslo, p 100-103

* Kovacs KM, Moore S, Overland JE, Lydersen C (2011b) Impacts of changing sea ice conditions on Arctic marine mammals. Mar Biodiv 41:181-194

Laidre KL, Heide-Jørgensen MP (2012) Springtime partitioning of Disko Bay, West Greenland by Arctic and subArctic baleen whales. ICES J Mar Sci 69:1226-1233

* Laidre KL, Heide-Jørgensen MP, Dietz R, Hobbs RC, Jørgensen OA (2003) Deep-diving by narwhals Monodon monoceros: differences in foraging behavior between wintering areas? Mar Ecol Prog Ser 261:269-281

Laidre KL, Stirling I, Lowry LF, Wiig $\varnothing$, Heide-Jørgensen MP, Ferguson SF (2008) Quantifying the sensitivity of arctic marine mammals to climate-induced habitat change. Ecol Appl 18:S97-S125

Laidre KL, Stern H, Kovacs KM, Lowry L and others (2015) Arctic marine mammal population status, sea ice habitat loss, and conservation recommendations for the 21st century. Conserv Biol 29:724-737

Lønø O, Øynes P (1961) White whale fishery at Spitsbergen. Norsk Hvalfangsttid 50:267-287

* Lydersen C, Martin AR, Kovacs KM, Gjertz I (2001) Summer and autumn movements of white whales Delphinapterus leucas in Svalbard, Norway. Mar Ecol Prog Ser 219: 265-274

Lydersen C, Nøst OA, Lovell P, McConnell BJ and others (2002) Salinity and temperature structure of a freezing Arctic fjord - monitored by white whales (Delphinapterus leucas). Geophys Res Lett 29:2119-2123

Lydersen C, Martin AR, Gjertz I, Kovacs KM (2007) Satellite tracking and diving behaviour of sub-adult narwhals (Monodon monoceros) in Svalbard, Norway. Polar Biol 30:437-442

*ydersen C, Freitas C, Wiig Ø, Bachmann L, Heide-Jørgensen MP, Swift R, Kovacs K (2012) Lost highway not forgotten: satellite tracking of a bowhead whale (Balaena mysticetus) from the Critically Endangered Spitsbergen stock. Arctic 65:76-86

Lydersen C, Assmy P, Falk-Petersen S, Kohler J and others (2014) The importance of tidewater glaciers for marine mammals and seabirds in Svalbard, Norway. J Mar Syst 129:452-471

Marques TA, Andersen M, Christensen-Dalsgaard S, Belikov $\mathrm{S}$ and others (2006) The use of global positioning systems to record distances in a helicopter line-transect survey. Wildl Soc Bull 34:759-763

Martin AR (ed) 1990. Whales and dolphins. Salamander Books, London

Martin AR, Smith TG, Cox OP (1993) Studying the behaviour and movements of high Arctic belugas with satellite telemetry. Symp Zool Soc Lond 66:195-210

* Michalsen K, Dalpadado P, Eriksen E, Gjøsæter H and others (2013) Marine living resources of the Barents Seaecosystem understanding and monitoring in a climate change perspective. Mar Biol Res 9:932-947

Moore SE (2016) Is it 'boom times' for baleen whales in the Pacific Arctic region? Biol Lett 12:20160251
Moore SE, Stafford KM, Melling H, Berchok C and others (2012) Comparing marine mammal acoustic habitats in Atlantic and Pacific sectors of the High Arctic: year-long records from Fram Strait and the Chukchi Plateau. Polar Biol 35:475-480

Nordli Ø, Przybylak R, Ogilvie AEJ, Isaksen K (2014) Longterm temperature trends and variability on Spitzbergen: the extended Svalbard airport temperature series, 18982012. Polar Res 33:21349

Øien N (1988) The distribution of killer whale (Orcinus orca) in the North Atlantic based on Norwegian catches, 1938-1981, and incidental sightings, 1967-1987. Rit Fiskideildar 11:65-78

Onarheim IH, Smedsrud LH, Ingvaldsen RB, Nilsen F (2014) Loss of sea ice during winter north of Svalbard. Tellus A 66:23933

* Overland JE, Wang M (2010) Large-scale atmospheric circulation changes associated with the recent loss of Arctic sea ice. Tellus A 62:1-9

* Palsbøll PJ, Heide-Jørgensen MP, Dietz R (1997) Population structure and seasonal movements of narwhals, Monodon monoceros, determined from mtDNA analysis. Heredity 78:284-292

*Pavlov AK, Tverberg V, Ivanov BV, Nilsen F, Falk-Petersen S, Granskog MA (2013) Warming of Atlantic water in two west Spitsbergen Fjords over the last century (19122009). Polar Res 32:11206

* Reeves RR, Ewins PJ, Agbayani S, Heide-Jørgensen MP and others (2014) Distribution of endemic cetaceans in relation to hydrocarbon development and commercial shipping in a warming Arctic. Mar Policy 44:375-389

Reilly SB, Bannister JL, Best PB, Brown M and others (2012) Balaena mysticetus (Svalbard-Barents Sea (Spitsbergen) subpopulation). The IUCN Red List of Threatened Species:e.T2472A17879836

Richard PR, Martin A, Orr JR (2001) Summer and autumn movements of belugas of the eastern Beaufort Sea stock. Arctic 54:223-236

* St Aubin DJ, Smith TG, Geraci JR (1990) Seasonal epidermal moult in beluga whales, Delphinapterus leucas. Can J Zool 68:359-367

* Stafford KM, Moore SE, Berchok CL, Wiig $\varnothing$ and others (2012) Spitsbergen's endangered bowhead whales sing through the polar night. Endang Species Res 18:95-103

* Stephenson SR, Smith LC (2015) Influence of climate model variability on projected Arctic shipping futures. Earth's Future 3:331-343

'Suydam R, Suydam RS, Lowry LF, Frost KJ, O'Corry-Crowe GM, Pikok D Jr (2001) Satellite tracking of eastern Chukchi Sea beluga whales into the Arctic Ocean. Arctic 54:237-243

Walsh JE (2008) Climate of the Arctic marine environment. Ecol Appl 18:S3-S22

Westdal KH, Richard PR, Orr JR (2013) Availability bias in population survey of northern Hudson Bay narwhal (Monodon monoceros). Polar Biol 36:1235-1241

Wiig Ø, Bachmann L, Janik VM, Kovacs KM, Lydersen C (2007) Spitsbergen bowhead whales revisited. Mar Mamm Sci 23:688-693

*Wiig Ø, Bachmann L, Øien N, Kovacs KM, Lydersen C (2010) Observations of bowhead whales (Balaena mysticetus) in the Svalbard area 1940-2009. Polar Biol 33: 979-984

Submitted: June 6, 2016; Accepted: November 14, 2016

Proofs received from author(s): January 23, 2017 